\title{
The morphological characteristics of the Muradiye Dönek pigeon, a native Turkish genetic resource
}

\author{
Fatma Tülin ÖZBAŞER ${ }^{1, a, ~}{ }^{凶}$, Evren ERDEM $^{2, \mathrm{~b}}$, Eser Kemal GÜRCAN $^{3, \mathrm{c}}$, Mehmet İ́hsan SOYSAL $^{3, \mathrm{~d}}$ \\ ${ }^{1}$ Tekirdağ Namık Kemal University, Faculty of Veterinary Medicine, Department of Animal Husbandry, Tekirdağ; ${ }^{2}$ Kırıkkale \\ University, Faculty of Veterinary Medicine, Department of Animal Husbandry, Kırıkkale; ${ }^{3}$ Tekirdağ Namık Kemal University, \\ Faculty of Agriculture, Department of Animal Husbandry, Tekirdağ, Turkey.

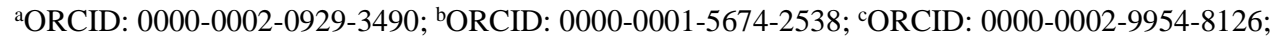
dORCID: 0000-0002-9992-8102.

${ }^{\square}$ Corresponding author: ftozbaser @ nku.edu.tr
Received date: 18.02 .2020 - Accepted date: 10.08 .2020

\begin{abstract}
This study was conducted to investigate the morphological characteristics of Muradiye Dönek pigeon. It is a local animal genetic resource and cultural heritage and has an important place among the genotypes of domestic pigeons in Turkey. The animal material of this study consisted of 100 pigeons (50 females and 50 males) from seven pigeon enterprises. In the study, morphological characteristics were evaluated and morphometric measurements were determined. Body plumage colors of pigeons were determined as black (70\%), red (16\%) and blue (14\%) galaca. In some birds, the yellow beaks and nails may bear black spots, which pigeon breeders refer to as 'zikir'. The term 'biyik' (mustache) is used when black feathers appear among the white feathers on the head, and the term 'kemer' (belt) is used when black feathers appear in the tail. The differences between the mean values of body weight and wingspan $(\mathrm{P}<0.001)$, chest depth $(\mathrm{P}<0.05)$ values were statically significant for age groups, which were reported to affect flight characteristics in birds. As a result, when the morphological characteristics obtained in Muradiye Dönek pigeons are compared with other researchers, it is thought that the selection of these birds were carried out by the breeders in terms of the game behavior such as rotation movement during the diving and landing. Although the data obtained in the study support the hypothesis that Muradiye Dönek pigeons should be defined as a different breed, further studies with DNA analysis are required to confirm this situation.
\end{abstract}

Keywords: Muradiye Dönek, morphological characteristics, pigeon, Turkey.

\section{Türkiye'nin yerli gen kaynağı, Muradiye Dönek güvercinlerinin morfolojik özellikleri}

Özet: Bu çalışma, Muradiye Dönek güvercinlerinin morfolojik özelliklerinin araştırılması amacıyla gerçekleştirilmiştir. Bu güvercinler Türkiye'nin yerli hayvan gen kaynağı olup kültürel mirasıdır ve evcil güvercin genotipleri arasında önemli bir yere sahiptir. Araştırmanın hayvan materyalini yedi işletmede bulunan toplam 100 adet (50 dişi ve 50 erkek) güvercin oluşmuştur. Çalışmada güvercinlerin morfolojik özellikler incelenmiş ve morfometrik özellikler belirlenmiştir. Güvercinlerde tüy rengi siyah (\%70), kırmızı (\%16) ve mavi (\%14) galaca olarak belirlenmiştir. Bazı kuşlarda sarı renkli gaga ve tırnaklarda güvercin yetiştiricilerinin 'zikir' olarak adlandırdığı siyah noktalar görülmektedir. Baş bölgesinde beyaz tüyler arasında siyah tüyler göründüğünde "bıyık", kuyrukta ise bu siyah tüyler "kemer" olarak adlandırılır. Kuşlarda uçuş özelliğini etkilediği düşünülen canlı ağırlık ve kanat açıklığ $(\mathrm{P}<0,001)$, göğüs derinliği $(\mathrm{P}<0,05)$ değerleri bakımından yaş grupları arasında farklılıklar önemli bulunmuştur. Sonuç olarak Muradiye Dönek güvercinlerinde elde edilen morfolojik özellikler yapılan çeşitli araştırmalar ile karşılaştırıldığında, bu kuşların dalma ve iniş esnasında dönme hareketi gibi sergiledikleri oyun davranışları yönünden yetiştiriciler tarafından seçildikleri düşünülmektedir. Bu çalışmada elde edilen veriler Muradiye Dönek güvercinlerinin farklı bir ırk olarak tanımlanması gerektiği hipotezini desteklese de, bu durumu doğrulamak için DNA analizleri ile gerçekleştirilecek gelecek çalışmalara ihtiyaç bulunmaktadır.

Anahtar sözcükler: Güvercin, Muradiye Dönek, morfolojik özellikler, Türkiye.

\section{Introduction}

Due to the wide variety of characteristics they present, pigeons have drawn the attention of fanciers and breeders around the world. These birds are believed to have been domesticated approximately 3000 years ago and have evolved into numerous varieties after intensive selective breeding $(6,14)$. While certain pigeon breeds are raised for their appearance (fancy/ornamental breeds), 
some others (flying/sporting breeds) are bred for their performance and playful behavior (rolling, diving, tumbling, spinning).

In addition, pigeon breeds differ from each other in their specific movements, with some demonstrating playful behavior (maneuvering and tumbling or sudden diving during flight, rotating around their own axes when descending). Maneuverability is described as the coordinated rapid movement of the wings, body, tail, and head (24).

The Dönek pigeons are classified as diving-spinning pigeons. While flying at a certain altitude, upon observing an object of interest (e.g. a female pigeon or a shiny spinning object), these birds are capable of closing their wings and performing a sudden dive. Pigeon breeders refer to anything that triggers this sudden dive as a 'shine' or a 'dove'. When diving, the wings are flapped once or more around the tail axis with a propelling movement. When spinning, some pigeons pull their wings in, and some keep their wings slightly open (25). Dönek pigeons are classified based on the region where they are raised, their morphological characteristics, and this spinning pattern during dives. Thus, several varieties exist, including 'Dolapci' and 'Selanik Dönek' (33).

The Muradiye Dönek pigeons have a long history in Anatolia and are a valuable part of the local animal genetic resources. However, to the knowledge, no previous study on the morphological characteristics of this breed has been published. Therefore, due to the paucity of information available on this particular topic, this study is aimed to increase the recognition of the Muradiye Dönek as a distinct breed by determining its morphological characteristics.

\section{Materials and Methods}

This study was approved by the Local Ethics Board for Animal Experiments of Tekirdağ Namık Kemal University, Turkey (2017/09). The study was conducted between February 2018 and March 2019 on Muradiye Dönek pigeons raised by the local enterprises of the Muradiye district of the Balikesir province, positioned between $39^{\circ} 04^{\prime}$ and $40^{\circ} 40$ northern latitudes and the $26^{\circ}$ $02^{\prime}$ and $23^{\circ} 02^{\prime}$ eastern longitudes.

The animal material of this study consisted of 100 pigeons (50 males and 50 females) from seven pigeon enterprises (including 12, 10, 22, 17, 12, 10, and 17 pigeons from each enterprise, respectively). The age and sex of the animals were determined on the basis of the records kept at the pigeon local enterprises. The pigeons were classified under the following age groups: 12-24 months (Group I), 25-35 months (Group II), 36-47 months (Group III), and $\geq 48$ months (Group IV). The pigeons were managed and fed according to the routine program of their pigeon enterprise. Each pigeon was identified through a detailed examination of its plumage color, presence or absence of markings, head crest and foot feathers (muffs), head structure, eye color, numbers of tail and wing feathers, and body weight. The wing feathers were counted in the order of the primary-axial and secondary (p-a-s) feathers. The plumage colors of the pigeons were described with the specific local terms used by the pigeon breeders in the study region. The birds were weighed on a precision balance accurate to $0.01 \mathrm{~g}$. The measurements of the body length were performed by using a metal ruler. Trunk length, wingspan, wing length, body length, tail length, and chest circumference measured with strip, while chest width and depth, head length and width, beak length and depth, and shank diameter measured with a digital caliper $(1,19,23)$.

The effects of environmental factors such as sex and age on some morphological characteristics were calculated with the General Linear Model (GLM). Statistical analyses were performed using SPSS 17 for Windows. A value of $\mathrm{P}<0.05$ was considered statistically significant. Tukey's multiple range test was used for multiple comparisons of the subgroups $(21,26)$. For this purpose, Tukey's multiple-range test was used to estimate some morphological measurements of the Dönek pigeon: Yijkl $=\mu+\mathrm{Ci}+\mathrm{Dj}+$ eijk, where $\mathrm{Y}=$ the dependent variable, $\mu=$ the overall mean, $\mathrm{Ci}=$ the fixed effect of sex ( $i=$ female or male), $\mathrm{Dj}=$ the fixed effect of the age group $(j=1,2,3,4)$, and eijklm $=$ the random error.

\section{Results}

According to this study, the head type was determined to be round shaped. The Muradiye Dönek was observed to have neither a head crest nor foot feathers (muffs). The birds were examined for wing pigmentation patterns (T-check, checker, bar, and barless) as described by Vickrey et al. (31). In the pigeons in this study, three types of wing color patterns were determined as T-Check (Figure 4A), checker (Figure 4B), and barless (Figure 4C). The pigeons observed in the study had no bar wing marks.

It was also determined that the head, wing, and tail feathers were white, whilst the remaining body feathers were either black, red, or blue. This multicolored appearance (mottled color) is called 'galaca' by the local pigeon breeders (Figure 4A, 4B, 4C). Breeders refer to birds who present livid grey feathers among black body plumage color as 'striped' (i.e. 'tabby' or 'tekir') (Figure 4D). In this study, the pigeons with livid grey and black plumage were classified under the 'black mottled (black galaca)' group. The eye color was either black (60\%), blue $(25 \%)$ or white $(15 \%)$. In general, the beak and nails are a light yellow color. In some birds, the yellow beaks and nails may bear black spots, which pigeon breeders refer to 
as 'zikir' (Figure 1). The term 'biyik' (i.e. 'mustache') is used when black feathers appear among the white feathers on the head (Figure 2), and the term 'kemer' (i.e. 'belt') is used when black feathers appear in the tail (Figure 2). The differences among the mean values of body weight, head length, beak depth, chest circumference, wing length, and shank diameter $(\mathrm{P}>0.001)$; head width, beak length, and chest width $(\mathrm{P}>0.01)$; and tail length and chest depth ( $P>0.05)$ were statically significant for sex groups. Furthermore, the age groups were determined to statistically differ in body weight, head width, chest circumference, wing length and span, shank diameter ( $P>0.001)$; head length, tail length $(\mathrm{P}>0.01)$; and chest depth $(\mathrm{P}>0.05)$. The morphological characteristics of the pigeons and their rates of incidence are presented in Table 1. Statistical values of certain morphological characteristics of the age and sex groups are shown in Table 2. The plumage colors and markings observed in the pigeons are shown in Figures 1, 2, and 4. While the eye colors are shown in Figure 3.
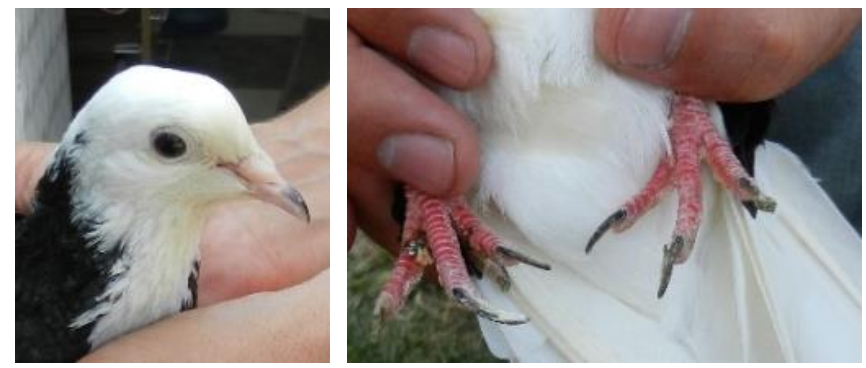

Figure 1. The black pigmentasyon on the beak and claw (Zikir).
Table 1. Some morphological characteristics in Muradiye Dönek pigeon.

\begin{tabular}{lc}
\hline Morphological characteristics & Ratio $(\boldsymbol{\%})$ \\
\hline Plumage colour & 70 \\
Black Galaca & 16 \\
Red Galaca & 14 \\
Blue Galaca & \\
Eye Colour & 60 \\
Black & 25 \\
Blue & 15 \\
White & \\
Marks & 7 \\
Zikir & 9 \\
Moustache & 5 \\
Belt & 79 \\
Unmarked & \\
The number of wing feather & 25 \\
$10-1-12$ & 48 \\
$10-1-10$ & 27 \\
10-1-9 & \\
The number of tail feather & 75 \\
14 feather & 25 \\
13 feather & \\
\hline
\end{tabular}

Figure 2. Pigmentations on the edge of the beak (mustache) and the tail (belt).
A

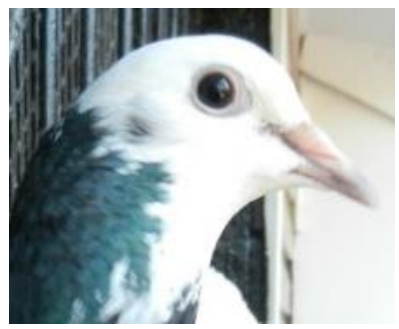

B

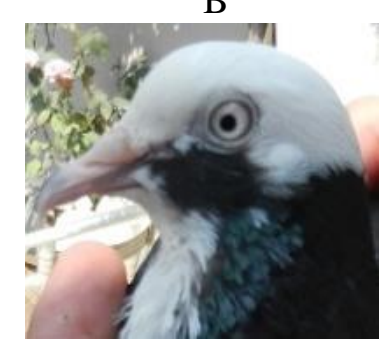

$\mathrm{C}$

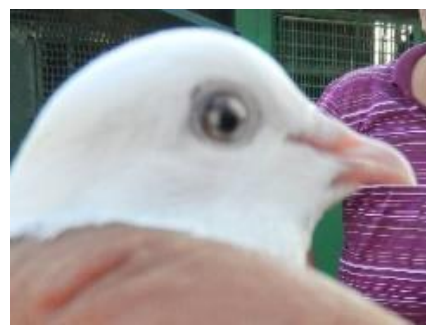

Figure 3. Eye colours of Muradiye Dönek pigeons (A: Black eye, B: White eye, C. Blue eye).
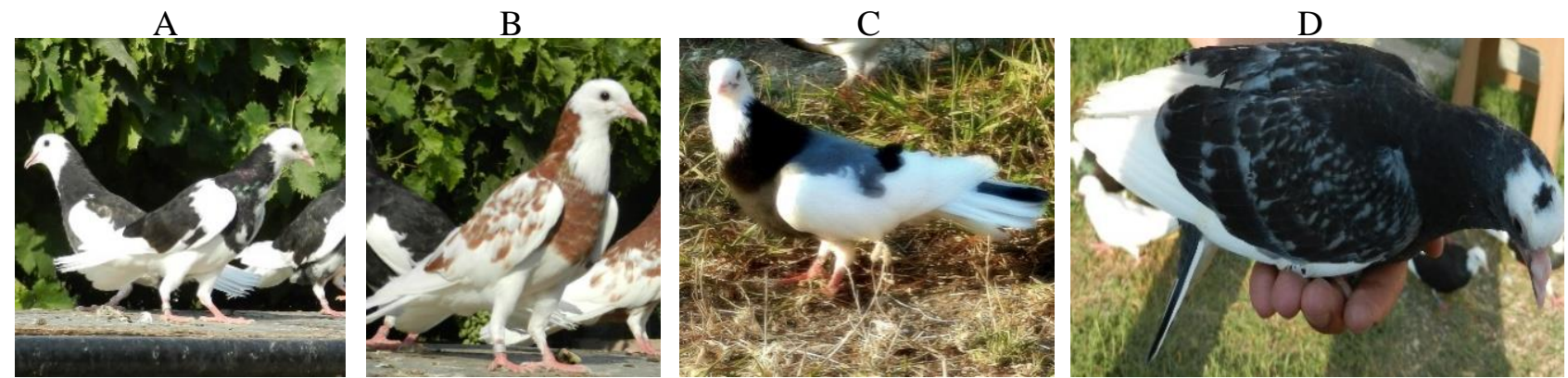

Figure 4. The body colours of Muradiye Dönek pigeons (A: Black galaca-wing structure, T-Check shaped; B: Red galaca-wing structure, checker-shaped; C: Blue galaca-garless; D: Tabby). 
Table 2. The statistical values of the morphometric characteristics detected from Muradiye Dönek pigeons $\left(X \pm S_{x}\right)$.

\begin{tabular}{|c|c|c|c|c|c|c|c|c|}
\hline DÖNEK & $\mathbf{n}$ & $\begin{array}{c}\text { Body } \\
\text { weight } \\
\text { (g) }\end{array}$ & $\begin{array}{c}\text { Head } \\
\text { length } \\
(\mathbf{m m})\end{array}$ & $\begin{array}{l}\text { Head } \\
\text { width } \\
(\mathbf{m m}) \\
\end{array}$ & $\begin{array}{c}\text { Beak } \\
\text { length } \\
(\mathbf{m m})\end{array}$ & $\begin{array}{r}\text { Beak } \\
\text { depth } \\
(\mathbf{m m})\end{array}$ & $\begin{array}{c}\text { Trunk } \\
\text { length } \\
(\mathrm{cm})\end{array}$ & $\begin{array}{c}\text { Tail } \\
\text { length } \\
(\mathbf{c m})\end{array}$ \\
\hline Total & 100 & $319.74 \pm 3.25$ & $52.44 \pm 0.23$ & $18.20 \pm 0.11$ & $18.76 \pm 0.14$ & $4.93 \pm 0.05$ & $10.66 \pm 0.09$ & $13.14 \pm 0.11$ \\
\hline Sex & & $* * *$ & $* * *$ & $* *$ & ** & $* * *$ & - & * \\
\hline Female & 50 & $306.34 \pm 4.45$ & $51.43 \pm 0.27$ & $17.84 \pm 0.13$ & $19.16 \pm 0.18$ & $4.64 \pm 0.06$ & $10.71 \pm 0.10$ & $12.86 \pm 0.11$ \\
\hline Male & 50 & $333.14 \pm 3.96$ & $53.45 \pm 0.31$ & $18.56 \pm 0.17$ & $18.37 \pm 0.21$ & $5.22 \pm 0.05$ & $10.62 \pm 0.15$ & $13.43 \pm 0.19$ \\
\hline Age & & $* * *$ & $* *$ & $* * *$ & - & - & - & $* *$ \\
\hline Group I & 25 & $318.63 \pm 5.19^{b}$ & $52.68 \pm 0.39^{\mathrm{b}}$ & $18.19 \pm 0.23^{b}$ & $18.38 \pm 0.37$ & $4.94 \pm 0.08$ & $10.47 \pm 0.19$ & $12.75 \pm 0.18^{\mathrm{a}}$ \\
\hline Group II & 20 & $318.71 \pm 7.42^{\mathrm{b}}$ & $52.37 \pm 0.60^{\mathrm{b}}$ & $18.23 \pm 0.20^{\mathrm{b}}$ & $19.25 \pm 0.38$ & $5.09 \pm 0.09$ & $10.98 \pm 0.18$ & $13.57 \pm 0.20^{\mathrm{b}}$ \\
\hline Group III & 22 & $285.13 \pm 4.86^{\mathrm{a}}$ & $50.94 \pm 0.34^{\mathrm{a}}$ & $17.15 \pm 0.20^{\mathrm{b}}$ & $18.68 \pm 0.26$ & $4.77 \pm 0.12$ & $10.45 \pm 0.15$ & $12.68 \pm 0.12^{\mathrm{a}}$ \\
\hline \multirow[t]{2}{*}{ Group IV } & 33 & $344.28 \pm 3.20^{\mathrm{c}}$ & $53.30 \pm 0.41^{\mathrm{b}}$ & $18.89 \pm 0.16^{\mathrm{c}}$ & $18.82 \pm 0.16$ & $4.94 \pm 0.09$ & $10.75 \pm 0.17$ & $13.50 \pm 0.25^{\mathrm{b}}$ \\
\hline & $\mathbf{n}$ & $\begin{array}{l}\text { Chest } \\
\text { depth } \\
(\mathbf{m m})\end{array}$ & $\begin{array}{c}\text { Chest } \\
\text { circumference } \\
(\mathbf{c m})\end{array}$ & $\begin{array}{l}\text { Chest } \\
\text { width } \\
(\mathbf{m m})\end{array}$ & $\begin{array}{c}\text { Wing } \\
\text { length } \\
(\mathrm{cm})\end{array}$ & $\begin{array}{l}\text { Wing } \\
\text { span } \\
(\mathrm{cm}) \\
\end{array}$ & $\begin{array}{c}\text { Body } \\
\text { length } \\
(\mathrm{cm})\end{array}$ & $\begin{array}{c}\text { Shank } \\
\text { diameter } \\
(\mathbf{m m})\end{array}$ \\
\hline Total & 100 & $57.81 \pm 0.35$ & $19.34 \pm 0.13$ & $49.94 \pm 0.35$ & $29.30 \pm 0.16$ & $67.57 \pm 0.60$ & $35.10 \pm 0.27$ & $3.51 \pm 0.04$ \\
\hline Sex & & $*$ & $* * *$ & $* *$ & $* * *$ & - & - & $* * *$ \\
\hline Female & 50 & $58.56 \pm 0.31$ & $18.90 \pm 0.23$ & $48.86 \pm 0.33$ & $28.69 \pm 0.21$ & $66.49 \pm 1.16$ & $34.87 \pm 0.38$ & $3.28 \pm 0.05$ \\
\hline Male & 50 & $57.05 \pm 0.62$ & $19.79 \pm 0.11$ & $51.02 \pm 0.58$ & $29.91 \pm 0.21$ & $68.66 \pm 0.24$ & $35.32 \pm 0.40$ & $3.74 \pm 0.06$ \\
\hline Age & & $*$ & $* * *$ & - & *** & $* * *$ & - & $* * *$ \\
\hline Group I & 25 & $59.26 \pm 0.54^{\mathrm{b}}$ & $18.96 \pm 0.22^{\mathrm{ab}}$ & $50.14 \pm 0.74$ & $28.92 \pm 0.29^{\mathrm{a}}$ & $68.00 \pm 0.37^{\mathrm{ab}}$ & $35.08 \pm 0.61$ & $3.55 \pm 0.09^{\mathrm{b}}$ \\
\hline Group II & 20 & $57.31 \pm 0.98^{\mathrm{a}}$ & $19.65 \pm 0.23^{\mathrm{bc}}$ & $50.54 \pm 1.12$ & $29.40 \pm 0.31^{\mathrm{b}}$ & $68.30 \pm 0.30^{\mathrm{b}}$ & $35.03 \pm 0.54$ & $3.62 \pm 0.07^{\mathrm{b}}$ \\
\hline Group III & 22 & $57.41 \pm 0.82^{\mathrm{a}}$ & $18.57 \pm 0.43^{\mathrm{a}}$ & $48.18 \pm 0.25$ & $27.81 \pm 0.35^{\mathrm{b}}$ & $67.16 \pm 0.28^{\mathrm{a}}$ & $34.57 \pm 0.51$ & $3.08 \pm 0.07^{\mathrm{a}}$ \\
\hline Group IV & 33 & $56.69 \pm 0.44^{\mathrm{a}}$ & $19.96 \pm 0.13^{\mathrm{c}}$ & $50.59 \pm 0.52$ & $30.52 \pm 0.19^{\mathrm{c}}$ & $69.51 \pm 0.24^{\mathrm{c}}$ & $35.50 \pm 0.52$ & $3.70 \pm 0.08^{b}$ \\
\hline
\end{tabular}

\section{Discussion and Conclusion}

Research shows that many domesticated pigeons raised today possess morphological and behavioral differences from their ancestors (3) because pigeons have undergone intensive selective breeding throughout history, resulting in the emergence of many varieties distributed across the world $(6,18,28)$. In particular, the Muradiye Dönek pigeons have been breeding for many years in Anatolia. However, to the knowledge, no reports on this particular pigeon breed have been published. Therefore, this study is the first investigation into the morphological characteristics of this pigeon genotype.

In the present study, it was ascertained that the sex groups significantly differed in body weight, head length, beak depth, chest circumference, wing length and shank diameter $(\mathrm{P}<0.001)$; head width, beak length, and chest width $(\mathrm{P}<0.01)$; and tail length and chest depth $(\mathrm{P}<0.05)$. These findings agree with the results of previous research, suggesting the existence of sexual dimorphism in the pigeons $(1,2,9)$. When morphological features were examined in age groups in pigeons, the average values of birds belonging to group III, excepting beak length and chest depth, were found lower than other groups. We think that the result may be explained with the sex distribution (18 females, 4 males) in group III. Wing size and bodyweight of birds are important factors affecting flight and racing performance in birds $(12,15,17)$. In this study, wing size (length and span) and body weight average values were detected to be higher in group IV pigeons compared to other groups. This difference may be due to the selection of those animals by the breeder and the frequency of training applied to animals in this group. Through this research, it was also proved that the differences observed among the age groups for beak length and depth were not statistically important $(\mathrm{P}>0.05)$. In contrast to the opinion that the structure of a beak may change with its utility or the bird's diet $(14,26)$, this observation suggests that the development of beak structure depends on non-dietary factors, such as the development of the skull $(4,13)$.

The head width, beak length, and beak width values determined in this study were similar to the previously reported values for the ancestor of domesticated (Columba livia) given by Jonnston (10) and Jonnston and Janiga (11), whilst the head length, wing length, and chest depth values were greater. The body weight measurements of the Muradiye Dönek pigeons were similar to the Pencil Pouter, the fancy breeds Archangel and Mookie, the drummer pigeon breeds Kokah and Bokhara Trumpeter and the Parlor Roller, Lotan, and Indian Tumbler pigeon breeds, which reported in different regions of the world (22). The Muradiye Dönek can be classified as a medium- 
sized pigeon breed when its body weight and some morphometric measurements (body length, chest width, head length) are compared to other pigeon breeds raised in Turkey and elsewhere, such as the Ankara Tumbler, Bursa Roller, Edremit Kelebek Roller, Thrace Roller, Dewlap (Adana), Scandaroon (Iskenderun) and fleet fliers (1, 2, 5, 19, 20, 22, 27, 34).

Pigeons have horizontally positioned eyes on two sides of their head. This position of the eyes allows these birds a panoramic vision of approximately $340^{\circ}$. The eye angle allows the pigeon to observe the detail of land and sky, thus escaping from predators (12). Research suggests that the position of the beak may affect the centering of the field of vision, the symmetry of the optic flow-field, direction of travel and time-to-contact (16). Pigeon fanciers who raise the Muradiye Dönek in Turkey expect these diving/spinning birds to immediately notice a 'shine' on the ground and perform a sudden dive towards it. The shape of the beak may play an important role in this ability to lock on a target and orient towards it. The mean beak length determined for the Muradiye Dönek $(18.76 \mathrm{~cm})$ was smaller than the mean beak lengths reported for Turkish roller pigeons (Thrace Roller and Bursa Roller) and Turkish diver pigeons (Edremit Kelebek Roller, Dewlap-Adana) and greater than the mean beak lengths reported for the Ankara Tumbler and Şanlıurfa Squadron flyer $(1,2,5,19,20,27)$. Furthermore, the mean beak depth determined for the Muradiye Dönek $(4.93 \mathrm{~cm})$ was smaller than the mean values previously reported for the Ankara Tumbler, Dewlap (Adana) and fleet fliers. This small beak depth and large beak length in the pigeon help to perceive the brightness more quickly and to direct towards it.

Another hypothesis addressed in this study stated that the phenotypic variety of pigeons is partly related to variances in plumage color. In the Muradiye Dönek, the plumage is 'mottled' and generally a combination of white feathers with red (16), black (70) or blue (14) feathers. Moreover, it was determined that the color combinations detected in the body, wing and tail in the pigeons showed random distribution. Some researchers have suggested that pigeons with different melanin pigmentation, in particular those with a dark plumage color, have developed different strategies to cope with feed restriction, including reducing their body mass index (7). The Muradiye Dönek may have developed such a strategy. To prevent the birds from flying, pigeon breeders do restrict the pigeons' access to feed. However, more detailed measurements and observations are needed before a conclusion can be drawn.

In previous research on the wing feather color patterns of pigeons, it was reported that a mutation in the Norrie Disease Protein (NDP) gene sequence, which impedes pigment production, results in the lightest 'barless' pattern and may also be associated with vision defects (31). In the Muradiye Dönek pigeons, darker wing pigmentation (86\%) was found to be more common than lighter wing pigmentation (14\%). Pigeon breeders may be responsible, as they attach importance to rapid reactions to shines and their Dönek pigeons with lighter pigmentation also possess vision defects, suggesting that this breed may have undergone selective breeding for visual acuity. However, the correlation between vision defects and genetic structure needs to be further investigated in more detail.

Previous research has also suggested that the flight capability and racing/sporting performance of pigeons can be affected by body weight, wing length, and chest depth and that birds with longer wings fly at a greater speed (8, 17). In the present study, based on morphometric measurements performed on the Muradiye Dönek, the mean body weight (319.74 g), mean wing length (29.30 $\mathrm{cm})$ and mean chest depth $(57.81 \mathrm{~cm})$ values were found to be smaller than the values previously reported for other sporting pigeon breeds, including the Thrace Roller, Bursa Roller, Edremit Kelebek Roller, Ankara Tumbler, and Dewlap (Adana), as well as fleet fliers raised in Turkey (1, $2,5,19,20,27)$. A bird's wingspan affects the thermoregulation of the body during flight and its flying speed and maneuverability $(30,32)$, and the flying speed seems to increase with a reduced wingspan (30). In the case of the Muradiye Dönek pigeons, the mean wingspan $(67.57 \mathrm{~cm})$ was found to be smaller than that reported for the Ankara Tumbler, fleet fliers, and Scandaroon (68.82 $\mathrm{cm}, 67.67 \mathrm{~cm}$, and $71.40 \mathrm{~cm}$, respectively) and greater than the values reported for the Edremit Kelebek Roller, Thrace Roller and Bursa Roller $(66.40 \mathrm{~cm}$ for males, 64.8 $\mathrm{cm}$ for females; $67.32 \mathrm{~cm}$ and $59.07 \mathrm{~cm}$, respectively) (1, $2,5,19,20,27,34)$. Thus, the general assessment of the body weight, chest depth, wing length, and wingspan data obtained in the present study suggests that fanciers of the Muradiye Dönek have subjected this breed to selective breeding not for flying speed, but for the playful behavior displayed by the bird when descending.

Animals, as an integral part of the local genetic resources of a country, are often investigated for their various morphological characteristics not only to shed light on phylogenetic research but also to develop more efficient production systems and to perform genetic improvement studies. The morphological characteristics determined for the Muradiye Dönek in the present study highlighted that this particular pigeon variety may be thought of as an individual breed native to Turkey. According to these results, the studies for registration as a new breed of these pigeons were started and these studies have been ongoing. Moreover, this morphological data needs to be supported with further DNA research. 


\section{Financial Support}

This work is supported by the Scientific Research Project Fund of Tekirdağ Namık Kemal University under project number 10.GA.17.138 (NKUBAP, Tekirdağ, Turkey).

\section{Ethical Statement}

This study was approved by the Local Ethics Board for Animal Experiments of Tekirdağ Namık Kemal University, Turkey (2017/09).

\section{Conflict of Interest}

The authors declared that there is no conflict of interest.

\section{References}

1. Atasoy F, Erdem E, Hacan Gücüyener Ö (2013): Ankara ilinde yetistirilen taklact güvercinlerde (Columba livia domestica) morfolojik özelliklerin belirlenmesi. Ankara Univ Vet Fak Derg, 60,135-143.

2. Balcı F, Ardıçlı S, Alpay F, et al (2018): The determination of some morphological characteristics of Bursa Oynart pigeon breed. Ankara Univ Vet Fak Derg, 65, 349-355.

3. Bartels T (2003): Variations in the morphology, distribution and arrangement of feathers in domesticated birds. J Exp Zool B Mol Dev Evol, 298, 91-108.

4. Brighta JA, Marugán-Lobónc J, Cobbe S N, et al (2016): The shapes of bird beaks are highly controlled by nondietary factors. PNAS, 113, 5352-5357.

5. Erdem H, Konyalı C, Savaş T (2018): Edremit kelebek güvercinlerinin morfolojik karakterizasyonu. ÇOMÜ Ziraat Fak Derg, 6, 93-100.

6. Hollender WF, Miller WJ (1981): Hereditary variants of behavior and vision in the pigeon. Iowa St J Res, 55, 323331.

7. Jacquin L, Recapet C, Bouche P, et al (2012): Melaninbased coloration reflects alternative strategies to cope with food limitation in pigeons. Behav Ecol, 23, 907-915.

8. Jilly B (2006): The possibilities of orientation and finding the way back. Anim Welf Ethol Hou Syst, 2, 10-33.

9. Johnston RF (1990): Variation in size and shape in pigeons, Columba livia. Wilson Bull, 102, 213-225.

10. Johnston RF (1992): Evolution in the Rock dove: Skeletal morphology. The Auk, 109, 530-542.

11. Johnston RE, Janiga M (1995): Feral Pigeons. Oxford Univ. Press, Oxford.

12. Jones MP, Pierce KE, Ward D (2007): Avian vision: a review of form and function with special consideration to birds of prey. J Exotic Pet Med, 16, 69-87.

13. Kulemeyer C, Asbahr K, Gunz P, et al (2009): Functional morphology and integration of corvid skulls $-a 3 D$ geometric morphometric approach. Front Zool, 6, 1-14.

14. Levi WM (1972): Making Pigeon Pay. Levi Publications, Australia.

15. Liang X, Yu J, Wang H, et al (2018): Post-hatching growth of the pectoralis muscle in pigeon and its functional implications. Anat Rec (Hoboken), 301, 1564-1569.
16. Matin GR (2017): What Drives Bird Vision? Bill control and predator detection overshadow flight. Front Neurosci, 11, 1-16.

17. Mercieca S, Jilly B, Gáspárdy A (2017): Connection among body measurements and flying speed of racing pigeon. Int J Agri Sci Food Technol, 3, 9-18.

18. Murton RK, Thearle RJP, Thompson J (1972): Ecological studies of the Feral pigeon, Columba livia var. 1. Population, breeding biology and methods of control. $\mathrm{J}$ Appl Ecol, 9, 835-874.

19. Özbaşer FT, Atasoy F, Erdem E, et al (2016): Filo güvercinlerinde (Columba livia domestica) bazı morfolojik özellikler. Ankara Univ Vet Fak Derg, 63, 171-177.

20. Özbaşer FT, Gündüz Ö (2018): Determination of morphological characteristics of Adana pigeons in province of Mersin. 4th International Conference on Engineering and Natural Sciences.424, Kiev Ukraine.

21. Özdamar K (2015): Paket Programları ile İstatistiksel Veri Analizi, Sözkesen Matbaacılık, Ankara.

22. Pares-Casanova PM, Kabır A (2019): Morphological diversification among pigeon breeds of different aptitudes. Wseas Trans Biol Biomed, 16, 1-9.

23. Pennycuick CJ (2008): Modelling the Flying Bird. Available at http://books.google.com.tr/. (Accessed June 05, 2018).

24. Ros IG, Biewener AA (2017): Pigeons (C. livia) follow their head during turning flight: Head stabilization underlies the visual control of flight. Front Neurosci, 11, 655.

25. Savaş T (2010): Dönek Irk1. Available at www.guvercinbirligi.com (Accessed November 10, 2019).

26. Soysal MI (2012): Biyometrinin Prensipleri (İstatistik I ve II ders notları), Trakya Üniversitesi Tekirdağ Ziraat Fakültesi, Tekirdağ.

27. Soysal MI, Gürcan EK, Akar T, et al (2011): Trakya'da yetiştirilen Trakya Makaracı güvercin ırkının çeşitli morfolojik özelliklerinin saptanması. Tekirdağ Ziraat Fak Derg, 8, 61-66.

28. Stringham SA, Mulroy EE, Xing J, et al (2012): Divergence, convergence, and the ancestry of feral populations in the domestic rock pigeon. Curr Biol, 22, 302-308.

29. Telleria JL, De la Hera I, Pérez-Tris J (2013): Morphological variation as a tool for monitoring bird populations; a review. Ardeola, 60, 191-224.

30. Thomas ARL (1996): The Flight of birds that have wings and a tail: Variable geometry expands the envelope of flight performance. J Theor Biol, 183, 237-245.

31. Vickrey AI, Bruders R, Kronenberg Z, et al (2018): Introgression of regulatory alleles and a missense coding mutation drive plumage pattern diversity in the rock pigeon. eLife, 7, e34803.

32. Ward S, Rayner JMV, Möller U, et al (1999): Heat transfer from starlings sturnus vulgaris during flight. J Exp Biol, 202, 1589-1602.

33. Yılmaz O, Savas T, Ertugrul M, et al (2013): The domestic livestock resources of Turkey: Inventory of pigeon groups and breeds with notes on breeder organizations. World's Poultry Sci J, 69, 265-278.

34. Yıldırım H, Dogan U, Cimrın TD (2018): Determination of the morphological characteristics of Scandaroon pigeon grown in the central of Hatay province (Columba livia domestica). Euasia Proc Sci Technol Eng Math, 2, 368-375. 